\title{
CONGENITAL ENLARGEMENT OF THE COLON AND RECTUM.
}

\author{
BY L. E. BARRINGTON-WARD, LONDON.
}

THE first full description of this disease was given by Hirschsprung in I8g6, and it has been customary to associate his name with the condition. It had, however, been recognized before that date, and according to Jayle, Ruyson in the I 7 th century described a fairly typical case in a girl of five years. Parry in I825, Billard in I829. Von Ammon in I842, published undoubted cases, which were followed by several others before Hirschsprung's paper appeared (Finney).

The disease, when developed, presents such a striking picture that it is not surprising to find that observers hasten to put their experiences on record, and the literature of the condition is considerable. Finney, in a comprehensive survey, discovered 206 references up to January ${ }_{x}$ I908, and gave an excellent summary of its chief points. I have found his paper of considerable value in the preparation of this thesis, and have read all those articles which influence the point ot view from which the subject is here approached, and all other accessible communications which have been made up to the present date.

The clinical features are well known, and it is not proposed to deal with that section at any length. Etiology and treatment offer a wider scope.

For the purpose of enquiring into the etiology I have taken the post-mortem records of all the cases of this nature at the Hospital for Sick Children, Great Ormond Street.

Inasmuch as in the records the old nomenclature of sigmoid colon and rectum was used, I have thought it advisable, in order to avoid confusion, to retain this description of the large bowel as far as possible, in preference to the newer division into iliac and pelvic colon and rectum

It is undoubtedly common to label as Hirschsprung's disease many conditions which are not so. Many of the recorded cases, especially of elderly males, are probably instances of an advanced degree of fæcal stasis: I have seen two or three such instances in infants, in which fissures about the anus caused a reflex spasm of the sphincters and prevented defæcation. With the onset of abdominal distention and vomiting, the diagniosis of Hirschsprung's disease was suggested. Treatment, viz., dilatation of the sphincter, at once differentiated this spurious form from the true variety. Post-mortem examination or operation is a certain test, and I have accordingly limited myself to cases verified by these means.

What is the best treatment to employ is still an unsettled question. I propose to give in some detail the treatment of five recent cases for which in three instances $I$ was partly responsible, and in which the results have surpassed any others that have been treated at the Children's Hospital, Great Ormond Street.

Definition.-The disease is perhaps most generally known by the name of Congenital Idiopathic Dilatation of the Colon.

vol. I.-NO. 3. 
Cases where any form of obstructing agent is demonstrable should be excluded. In its most typical form, congenital enlargement of the colon is manifested by progressive constipation and intestinal distention dating from birth. A form of the disease was described by Hirschsprung, which occurs in later years, and has been given the misnomer of pseudo-megacolon. Many of the cases described as such are not true examples of congenital enlargement, but are due to varjous kinds of mechanical obstruction, and some to simple stasis. That the true congenital disease may occur in later life must be admitted, but such instances are rare and are in every way comparable to the occasional appearance of apparently typical cases of congenital pyloric obstruction in adult life.

Emphasis is usually laid on the dilatation of the intestine. The hypertrophy, however, is no less striking a feature, and has been described as present

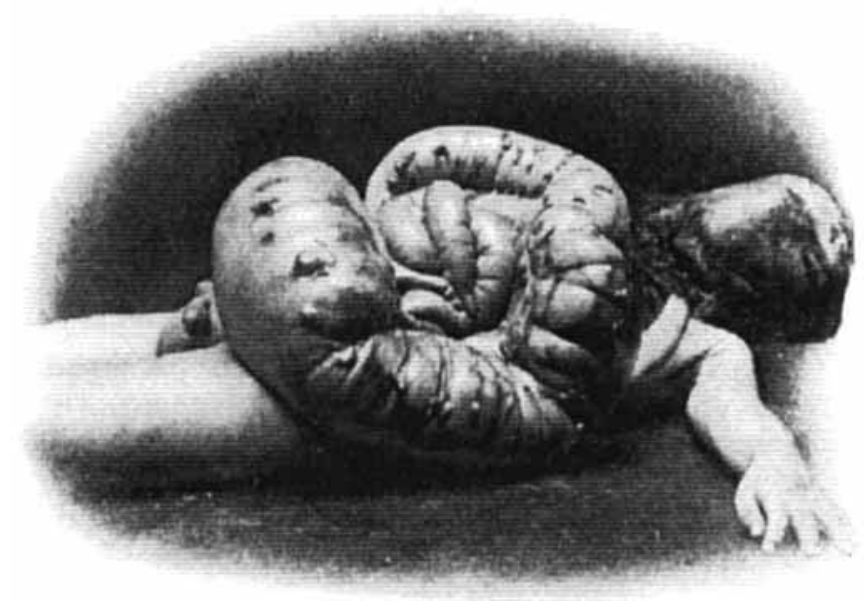

Frg. 209.-Case I7. The huge size of the colon is well shown. (Photo by G. B. Wainwright.)

at birth (Billard, Joukovsky). If this is a secondary hypertrophy it is necessary to assume that there is an intra-uterine factor at work. Further attention will be paid to this point in discussing the etiology.

It is described as a disease of the colon, and the sigmoid colon has attracted most attention. The huge sigmoid is undoubtedly a feature of the condition, (Fig. 209), but I shall hope to show that it is not necessarily in the colon that the most marked changes are found.

It is the function of the sigmoid to act as a reservoir for fæces, and in virtue of its wide mesentery its capacity for distention in the normal is considerable. Therefore, in any distention affecting the large bowel as a whole, the change will be most marked in the sigmoid.

Observations as to the condition of the rectum proper in these cases are often incomplete. Of fifteen of my cases in which a definite examination of this part was made at autopsy, in thirteen the rectum was noted as dilated and 
hypertrophied to the anus. In four cases during life this has been suggested by radiograms after bismuth meals and has been verified at operation.

It must therefore be conceded that the term congenital dilatation of the colon is incorrect in that it does not express the hypertrophy that so constantly accompanies the dilatation, and does not include the rectum, which in many of these cases shows the most interesting changes. Congenital enlargement of the rectum and colon more accurately expresses the condition of affairs.

Etiology.-Finney has made a complete collection of the numerous theories that have been put forward in explanation of this disease. They may be classified under the headings of mechanical, neuropathic, inflammatory, and congenital. To say that the condition is congenital is of little assistance; it merely means that it is an error of development which our present knowledge of pre-natal pathology is insufficient to explain. Yet it will be of some assistance to determine whether the disease can come under this heading, or whether it is due to some factor acting post-natally which may be controlled by the methods at present at our disposal.

It has been suggested that the cause may be :-

A. Mechanical :-

I. An abnormally long mesentery permitting torsion of the sigmoid (Barth)

2. Increased length of the intestine, especially the sigmoid, which throws the bowel into loops, and causes kinking and obstruction (Marfan, Neter)

3. Atresia of the rectum and anus (Treves)

4. Valve formation (Perthes, Roser)

5. Distention of pelvic colon with meconium at birth and valve action (Wilkie)

B. Neuropathic:-

I. Neuromuscular defect of a segment of the intestine (Hawkins)

2. Paralysis of a segment of intestine (Pennato).

3. A lesion of the sympathetic (Bing)

4. Reflex spasm of the sphincters due to anal fissures (Fenwick)

C. Inflammatory:-

Colitis becoming chronic.

D. Congenital :--

r. Anomaly of development-dilatation and hypertrophy congenital. (Hirschsprung)

2. Dilatation congenital, hypertrophy secondary (Mya, Concetti)

3. Hypertrophy congenital, dilatation secondary (Fenwick, Genersich)

These theories will be considered in the light of this series of cases, briefly summarizing the main points discovered at post-mortem examination.

A.--Between the years I868 and IgI2 post-mortem examinations were made at the Hospital for Sick Children on I9 undoubted cases of Hirschsprung's 
disease. Of these 16 were males and 3 females. The youngest was 3 weeks, the oldest 12 years old. Ten of them were I year of age and under, and six between $I$ and 5. Thirteen had received medical treatment; six had undergone surgical operations.

In all cases it was noted that the sigmoid colon was hypertrophied. In twelve cases the rectum was affected, either hypertrophied, or dilated, or both: in two it was said to be normal; in five cases no statement was made as to the condition of the rectum. In no case was any mechanical obstruction to be found, though in one the bowel was said to be kinked as it turned into the pelvis.

I would lay particular stress on the condition of the rectum in these cases. In many of the reported cases the rectum is said to be normal, but in the routine autopsy the bowel is not dissected out entire, down to and including the anus, but is cut across at an accessible point in the pelvis. In this manner hypertrophy of the rectum without much dilatation could easily be overlooked.

In ten cases of this series it is definitely stated that the hypertrophy of the rectum extended down to the anal canal. These are independent observations of a number of different pathologists extending over a period of forty-four years. Assuming this to be a common feature, it at once excludes many of the suggested theories. In several of the cases it is stated that the thickening of the walls of the gut became progressively greater towards the anus. No external or internal factor of any kind was found to act as an obstructing agent. The fault must have been in the wall itself. The anus was in every case normal. In three cases, a thickening was to be felt just above the anal canal, and the observers likened it to the feel of a congenital hypertrophic pylorus. In these circumstances any theory as to a mechanical cause, whether it be kinking of the gut, torsion of the sigmoid from an abnormally long mesentery or from abnormal length of the gut itself, is untenable. The last part of the rectum takes a practically straight course before passing into the anal canal, and in none of these cases was any abnormality to be discovered in the valves of Houston.

$B$.-The neuropathic theories are difficult to prove or disprove. Histological changes in the sympathetic are not easy to show, although Finney states that in two cases he found apparently healthy ganglion cells in both Meissner's and Auerbach's plexuses.

C.-The age, the marked sex preponderance, the history that in all but three of the cases (the time of onset in these cases was 2 months, 6 months, and 3 years 9 months), constipation had dated from birth, appear to my mind almost conclusive proof that the condition is, for want of a better term, a congenital one. Finney brings forward from the literature strong evidence in favour of Hirschsprung's conception of the disease. Several cases are on record of its being present at birth. Joukovsky describes a case which is I believe the key to the whole question. It was that of a new-born child with ectasia of the large intestine, with hypertrophy of the whole of the intestinal tract, and with stenosis of the duodenum.

If such an error can take place in the development of the whole of the intestine, it is not unreasonable to assume that it may with more frequency affect only a part of the intestine. Errors of development are especially prone to occur in the region of the junction of the proctodæum and hind gut and the junction 
of the fore and mid gut. In this connection the similarity of congenital pyloric stenosis to congenital disease of the colon and rectum is striking.

The close similarity of the age of onset, the sex incidence, and the histology, well deserve examination. Both conditions may be present at birth. I have seen a perfect example of hypertrophic stenosis of the pylorus in a male infant of three days; this case was admitted to the Hospital for Sick Children under the care of Mr. Tyrrell Gray, on September 20, I9I2, with a history of persistent vomiting. The diagnosis of a high intestinal obstruction or atresia was made, and at operation a markedly thickened and stenosed pylorus was discovered. The infant succumbed, and at the autopsy this condition was verified.

Characteristic symptoms of pyloric stenosis occur at about four to six weeks after birth, and the symptoms are probably due to the associated gastritis from gastric stasis and fermentation, and it is not until infection of the mucous membrane occurs that vomiting becomes a feature. Successful medical treatmentlavage-is directed to the cure of the gastritis.

In the case of Hirschsprung's disease, at first the symptoms are of constipation only and little harm results. It is with the onset of colitis at about the second or third month that characteristic and harmful symptoms develop. Fermentation changes increase the abdominal distention which, as a rule, attracts attention at about this time.

Again, in both conditions symptoms may be delayed to later life. Barling has reported instances of apparently true congenital hypertrophic stenosis of the pylorus in two patients aged I7 and 27 years. In neither case had symptoms been shown in childhood.

Congenital disease of the pylorus and colon may be theoretically explained by assuming a nerve lesion which places a block on the intestinal canal in these regions; but in view of the condition having been found at birth, it is necessary that movements of the intestinal canal should have been active for some time pre-natally. The nerve lesion, if there is one, is more likely to be of a trophic nature in the failure of regulation of the growth of the parts. We know so little of the control of the development of the body that it is perhaps idle to speculate.

Gigantism or asymmetrical overgrowth of the extremities and different parts of the body, has long been recognized, and there seems no reason why such pre-natal overgrowths or potential overgrowth should not be allowed in the case of the intestine. Finney, in the description of his own case, draws attention to the large size of the blood-vessels and lymphatics, and compares it to a lymphangiectasis such as is met with elsewhere.

Most observers are agreed on the histological changes. In those of the present series which were submitted to histological examination, the hypertrophy and hyperplasia of the muscular coats-especially the circular-were the characteristic features. Changes in the submucosa and the mucosa were of the nature of round-celled infiltration, such as would be expected from the generally associated colitis.

A satisfactory theory that will explain all the cases that have been reported as instances of congenital megacolon is impossible. Many of these cannot properly be classified as congenital colon disease at all. I believe the theory that best explains this series of cases is as follows:- 
There is a congenital abnormality in the lower end of the hind gut which takes the form of a muscular hyperplasia. It usually involves the rectum and extends for a varying distance up the pelvic and iliac colon. It may be that the whole of the hind gut is affected. In some cases there is a definite localization of the change, e.g., Cases 2, I2, and I4, where the hyperplasia has affected a segment of the intestine chiefly. The hyperplasia of the muscle gives rise to both thickening of the walls and increase of the lumen. The physiological functions. of the intestine are in abeyance, a block is produced, and the bowel behind, for a varying distance depending on the extent and duration of the condition, dilates and hypertrophies. This fæcal stasis in time produces inflammatory changes in the mucosa, and an ulcerative colitis occurs which is the cause of death in most instances.

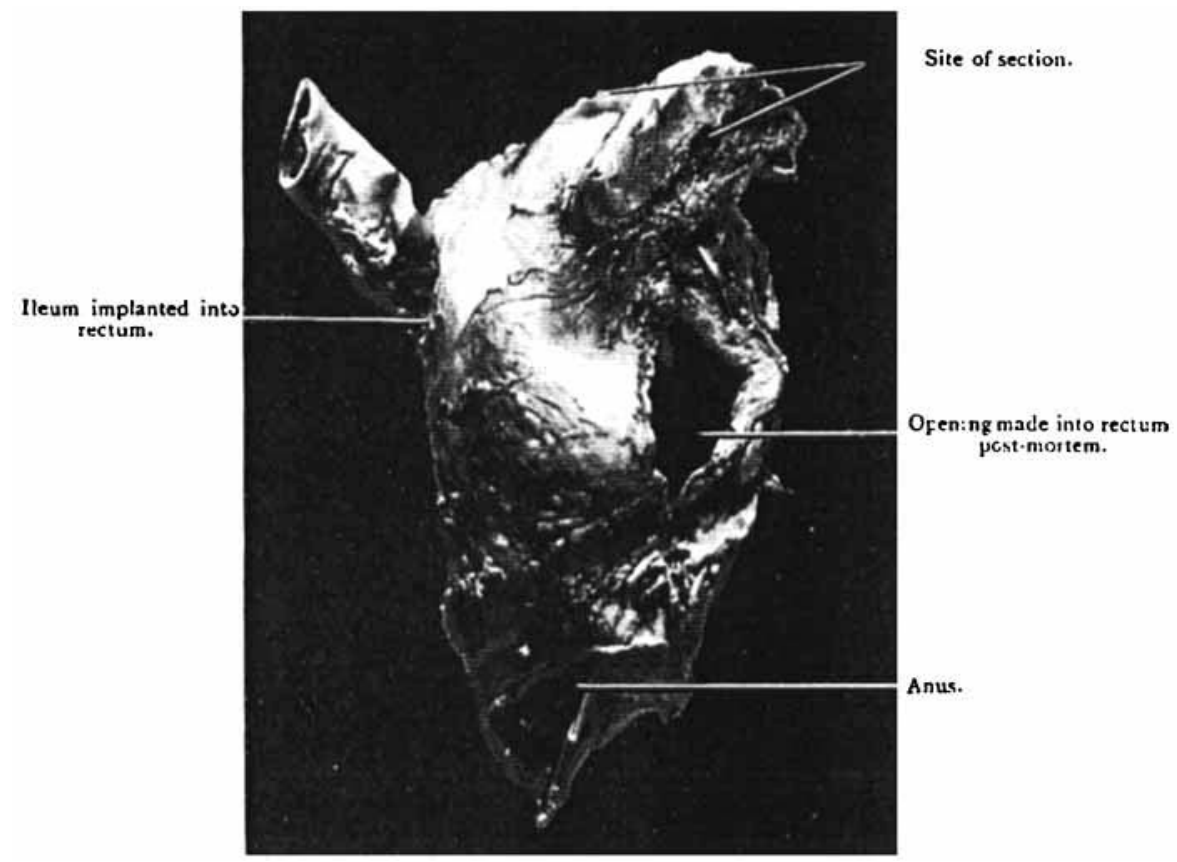

FIG. 210.-Specimen from Case I, consisting of the lower part of the rectum and anus, with the ileum entering it above. The dilated rectum has been opened to show the great hypertrophy of its wall. The patient died three days after operation. At the post-mortem, healing was advanced both where the ileum had been inserted and where the rectum had been cut across, and no leakage had occurred.

The Clinical Features are distinctive.-The salient points are intractable constipation and enlargement of the abdomen. The constipation in fifteen out of eighteen cases dated from birth. In one case no note as to this fact was made. The enlargement of the abdomen has been met with at birth. In these cases it was most commonly noted between the second and fourth month, that is to say, at a time when the colitis was appearing. If the child survives to any age, the distention may assume enormous proportions. The literature abounds in examples of prodigious enlargement. 
In a few cases compensation may be established, and the symptoms are not sufficient to bring the patient under medical observation until some years have elapsed.

Of the nineteen cases, ten were $I$ year of age and under, and six between the ages of $x$ year and 5 years.

As a rule, diarrhœa begins sooner or later, and alternates with the constipation. Some cases remain comparatively well for periods between attacks

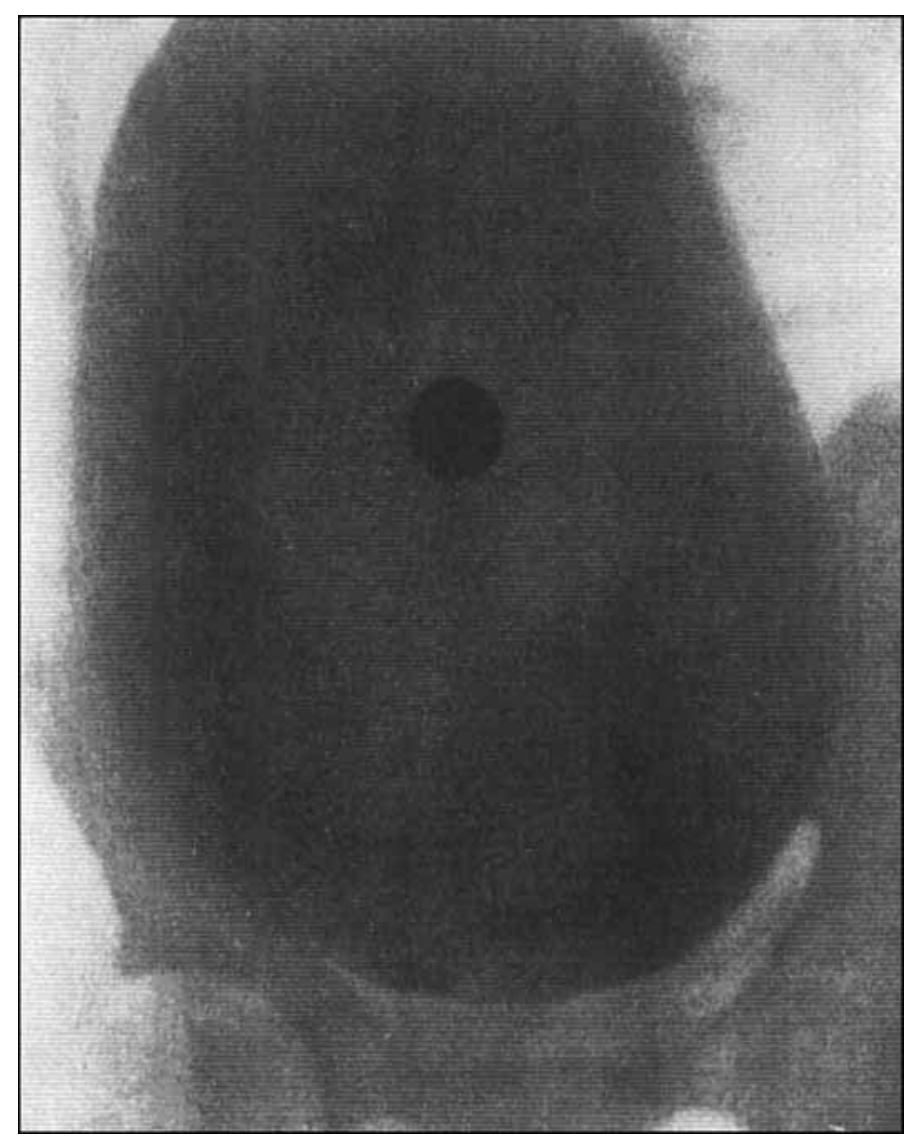

Fig. 211 .-Radiogram of Case $\mathrm{x}, \mathrm{I} 52$ hours after a bismuth meal. The enormous size of the rectum is well seen.

of constipation and diarrhœa. It seems that compensation can break down and again be re-established. Any one of these attacks may be fatal. However well the patients appear between the attacks, purgative medicines and enemata are always required. Long intervals of time may elapse between the actions of the bowels. In one of my cases, three weeks was the usual interval, but many more striking instances have been recorded.

Abdominal pain sometimes occurs, but generally not until the later stages. 


\section{2}

\section{THE BRITISH JOURNAL OF SURGERY}

Vomiting is not a common feature, but one of these cases died from incessant vomiting at the age of three weeks.

The general features of auto-intoxication are well marked. Staining of the skin, emaciation, lethargy, foulness of the breath, a low blood-pressure, and coldness of the extremities, are present in every case of any standing.

The distended intestines produce pressure effects on the abdominal contents, and œdema of the legs, ascites, and collapse of the bases of the lungs result. One case had hydronephrosis.

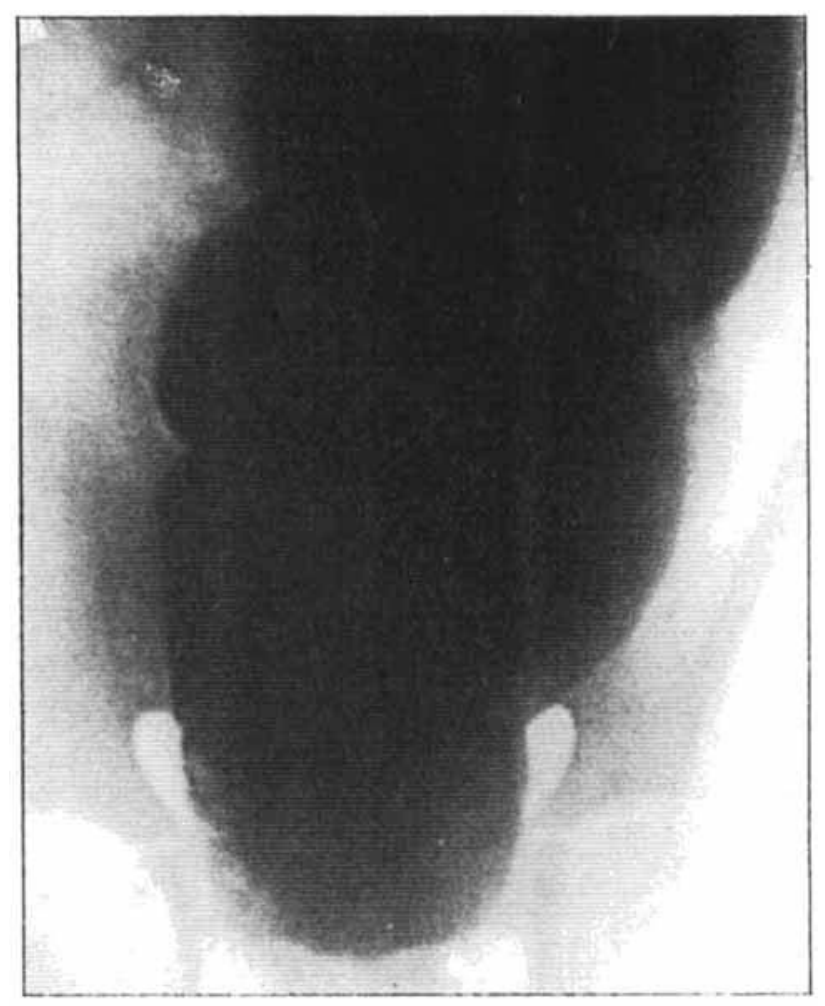

FIG. 212.-Case 2. Radiogram 52 hours after bismuth meal, showing dilated rectum.

The abdomen is tense, the abdominal wall has a glazed appearance and is marked by dilated veins.

Peristalsis, especially in infants, is generally obvious. On palpation, the tension may be such that nothing definite can be felt, or the frecal masses may be distinctly palpable and may give rise to the erroneous diagnosis of abdominal tuberculosis. In favourable cases the distended segment of the intestine may be actually palpated.

On rectal examination the anus and sphincters are normal. In three cases where I have had the opportunity of performing this examination, the examining finger easily palpated the distended lower part of the rectum, which was filled 


\section{ENLARGEMENT OF COLON AND RECTUM 353}

with tenacious fæcal material. I was unable to satisfy myself that. I could feel any thickening of the rectal wall. In one case later, autopsy revealed enormous thickening of the rectal wall right down to the anus (Fig. 2Io).

Diagnosis.-This is easy in typical cases. Stress should be laid on the history, the constipation, and the abdominal enlargement.

A digital examination of the rectum and anus will exclude spasm of the sphincters, and simple atresia of these parts.

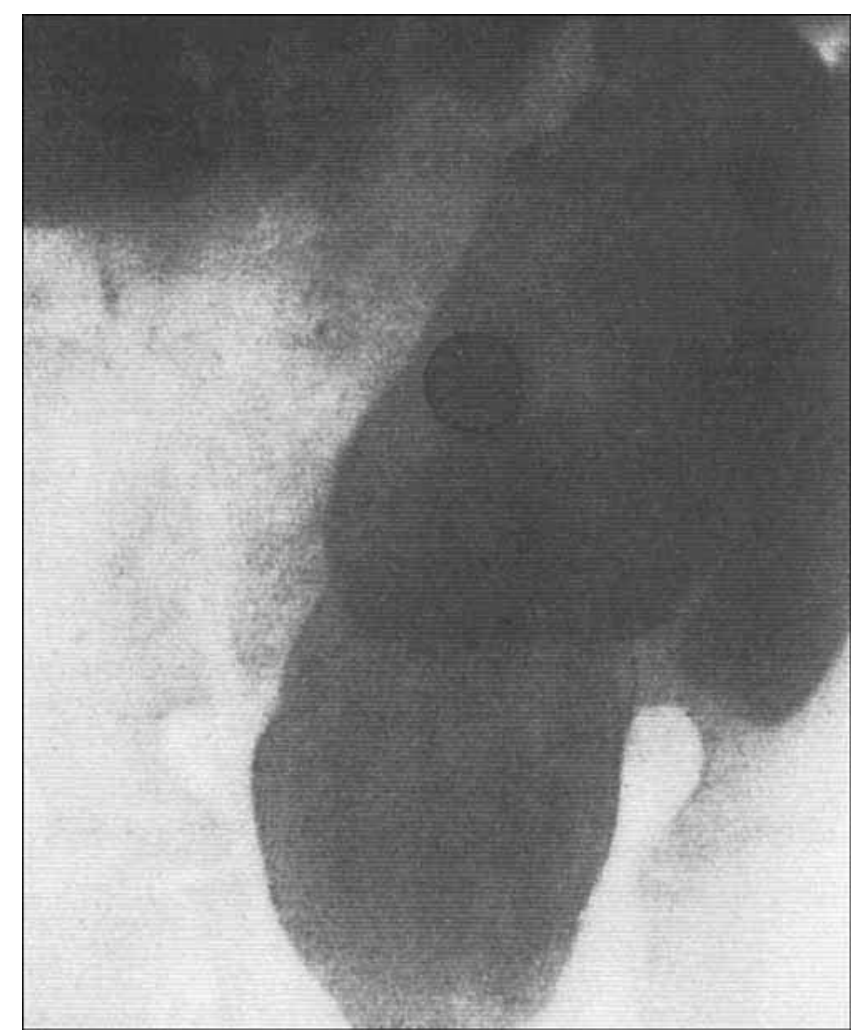

FIG 2r3.-Case 3. Radiogram of pelvis, showing the size of the rectum] 84 hours after bismuth mea!

The matted form of abdominal tuberculosis bears at times a superficial resemblance.

Excellent confirmatory evidence is obtained by examination with the $x$-rays after a bismuth meal. Appended are radiograms of the pelvic colon and rectum in three cases (Figs. 2II, 2I2, 2I3).

Treatment.-The treatment of this disease has been unsatisfactory, as is shown by the variety of the methods that have been employed from time to time.

In the first place it is necessary to decide the relative value of medical and 


\section{THE BRITISH JOURNAL OF SURGERY}

surgical treatment. The consensus of opinion seems to be that surgical treatment offers the greater hope. If the condition is at all established, it is difficult to see how medical measures can help. Drugs rapidly lose all their power on the inert bowel; enemata are generally retained, or returned without effect. The rectal tube is uncertain in its action, and can only be a temporary expedient.

In two cases, courses of pituitary extract (hypodermically), hormonal (splenic extract), and suprarenal extract, were given without the least effect.

Several writers have collected figures showing the relative mortality of cases treated medically and surgically. Duval gives a mortality of 74 per cent with medical and 34 per cent with surgical treatment. Lowenstein in fifty-nine cases dealt with on medical lines found the mortality 66 per cent, whereas of fortyfour treated by surgery the mortality was 48 per cent. Terry collected IIO cases treated surgically, with a mortality of 25 per cent.

It is therefore justifiable to say that surgery holds out better prospects of recovery than medicine and a fair estimate of the surgical mortality would appear to be about 36 per cent.

If the condition is a congenital malformation, medical measures can hardly have any curative effect. Cathartics may cause occasional evacuations by irritation; enemata may wash out any fæcal material lying in the lower part of the rectum; but neither cathartics nor enemata can restore the hyperplastic and hypertrophic bowel to its normal size, or reinitiate the normal peristalsis. The prolonged use of drastic purgatives, especially in infants, is dangerous. Many of the cases of this series were brought to hospital by the parents because of abdominal enlargement and constipation. In other respects they were fairly well. After a few days in hospital their condition became suddenly worse, diarrhœa set in, and collapse and death followed. This was in all probability due to the efforts of the physicians to clear the bowels with purgatives, which incidentally set up a fatal colitis. Post-mortem examination in these cases showed ulceration of the mucosa.

Other measures, such as massage, dieting, electricity, can only have a temporary effect on cases of undoubted Hirschsprung's disease : they may have a curative effect on the simple constipation of children.

The surgical treatment has been most varied. Cheadle claimed to have cured a case by simple puncture of the colon through the abdominal wall. The method is not likely to commend itself to most surgeons. Simple laparotomy has been performed, and the contents have been squeezed out of the anus, with temporary relief. This procedure has a field of usefulness as a preliminary to other treatment, but cannot be considered as a curative measure. Colostomy has been a favourite mode of treatment, but young children stand colostomy badly, and it is open to question whether death would not be preferable to an artificial anus acting throughout adolescence and adult life. Colostomy has been of use as a preliminary to other measures. Appendicostomy has not been followed by permanent good results.

Colopexy, coloplasty, colonplication, have all been attempted and have been abandoned. The basis of this form of treatment is founded on an incorrect idea of the pathology.

Intestinal exclusion by a short-circuiting operation is an excellent temporary and preliminary form of treatment. 
The ideal form of treatment is the removal of the whole of the affected bowel down to the anus (Fig. 2I4). Treves made a complete excision of the anus, rectum, and descending colon, and brought the transverse colon to the perineum. He hoped that control would be regained later. The operation is rendered. easier if the last part of the rectum is retained, and the final results justify its retention.

As the problem of treatment is frequently presented in the first few years of life, such heroic measures would be doomed to failure. In young children the operation should be performed in two stages. At the first operation the ileum is divided and implanted as low down in the rectum as possible. The open pelvis of the child permits the junction to be made at a lower level than would be possible in the adult. The junction has to be made with the greatest care, as the tissues of the rectum do not lend themselves to ready manipulation, and the risk of leakage and peritonitis is considerable.

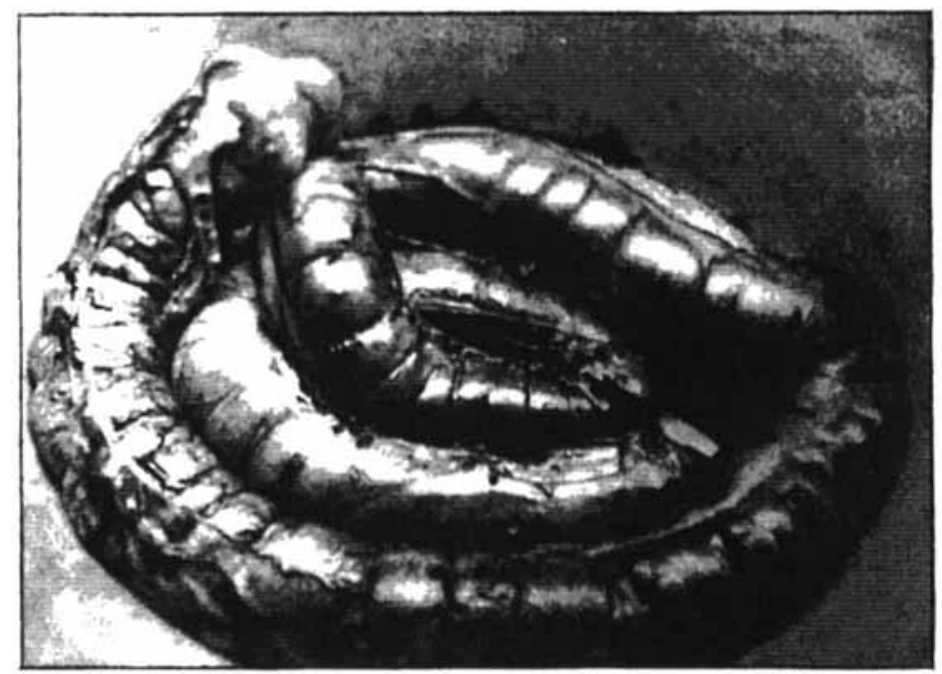

Fic. 2r 4.--Large intestine successfully removed from a boy, aged 6 , the subject of Hirschsprung's disease. (See Case 2.)

This operation may give the patient relief for several months. The fluid contents of the ileum find a ready exit through the shortened rectum, and the blocking of the colon and rectum above prevent regurgitation to any harmful extent. The child's strength improves, and at a favourable opportunity; some months later, the large bowel above the anastomosis is excised.

The operation may be a very simple one. This is especially the case if the gut is large and is provided with a distinct mesentery, and the vessels can be controlled in a series of pedicles. The operation is more difficult if the huge size of the bowel has encroached on the mesenteric interval.

The operation leaves the patient with the ileum entering the dilated terminal portion of the rectum. It is true that this must be considered a theoretical disadvantage, but in practice we have found that the fluid contents of the small 


\section{THE BRITISH JOURNAL OF SURGERY}

intestine do not tend to lie in the rectum to any extent, the control is good, and the bowels move normally after this operation. If the fæces do tend to collect, which is rare, it is an easy matter to wash out the relatively small cavity left so near the anus. (See Fig. 2Io.)

None of the cases treated are of sufficient standing to decide positively whether the ileum will dilate above the new anastomosis; but with constant care to keep the rectal sac empty this should not occur.

In some favourable cases it may be more satisfactory to complete the operation in one stage. More particularly will this be the case when the patient is of some age and in good condition, and when the size of the colon is such that the reposition of the abdominal contents would be difficult and would waste valuable time. The secret of success in these operations is speed. The shock is surprisingly small, and varies directly with the exposure of the patient and the amount of anæsthetic employed. Open ether anæsthesia should be used in all cases.

Saline subcutaneous infusion during the operation and for thirty-six hours afterwards is invaluable.

Treatment on the lines indicated has been employed by Sir Arbuthnot Lane on five patients during the last year. Four have made perfect recoveries, and the fifth died as the result of an unfortunate accident, namely, the slipping of a ligature, but for which $I$ believe he would have made a good recovery. Their ages were $3,6,9,10 \frac{1}{2}$, and $\mathrm{I} 2$ years; they were all instances of the disease in an extreme form, and they had all failed to react to medical treatment employed over long periods.

Case 1.-R. L., male, aged 12, Was admitted to the Hospital on August 18, 1912. He had had difficulty with his bowels all his life, and had never had a motion witlrout medicine and injections. The abdomen had gradually become more distended. He occasionally had abdominal pain. Three weeks was the usual interval between the motions. He was a well-developed but thin boy, with the usual signs of intestina] toxæmia. The abdomen was very latge, and was so tense that nothing definite could be palpated. On rectal examination, the finger passed into a huge cavity filled with fæces. Enemata produced no result. A bismuth meal and radiograms showed enormous distention of the colon and rectum ( $F i g .2 \mathrm{II})$.

On October $x$, Sir Arbuthnot Lane operated. On opening the abdomen, the pelvic colon eight inches in diameter presented. The ileum was divided and the proximal end implanted low down into the beginning of the rectum. The pelvic colon was then cut across above the junction, and the entire large bowel removed. The vessels of the colon were of a remarkable size. The operation had practically been completed, and had been exceedingly well borne, when an alarming hæmorrhage took place from slipping of the ligature on the left colic artery. It was controlled with great difficulty, and the patient lost much blood. His condition became at once grave, but improved with intravenous saline. Unfortunately, he never rallied from the severe hæmorrhage, and died on the third day following operation. Post mortem there was no peritonitis. All the parts were healing satisfactorily. The rectum was found to be enormously hypertrophied, more so than the pelvic colon (Fig. 2II).

Case 2.-E. W., male, aged 6. Transferred from a medical ward on October 24, I9I2. He had been constipated since birth, but symptoms had become more troublesome during the past year. Medical measures had failed to relieve him at all. His abdomen was distended. The enlarged colon and rectum could be palpated, and were rendered evident by bismuth radiograms. On October 25, Sir Arbuthnot Lane divided the ileum and implanted the proximal end into the upper end of the rectum. 


\section{ENLARGEMENT OF COLON AND RECTUM}

He was greatly relieved by this operation, and for some time passed normal stools, but the tendency to constipation returned, and on February 4, I913, the entire large bowel down to the rectum was excised. There was practically no shock, and he made a perfect recovery. His bowels have been acting normally since the operation.

Case 3.-H. B., male, aged 10 $\frac{1}{2}$. Admitted on January 3, Igr3. He had always been constipated. Had never had proper control of his bowels since infancy. At times the abdomen was very large. The abdomen was exceedingly tense and protuberant. There was tenderness in the left iliac fossa. On rectal examination, a very dilated rectum was palpated. The bismuth radiogram confirmed this, and showed great enlargement of the transverse, descending, and pelvic colon. On February 28, Sir Arbuthnot Lane excised the large intestine and implanted the ileum into the rectum. Recovery was excellent, and one month after operation defæcation was normal.

Case 4.-(I have to thank Dr. F. N. G. Starr, of Toronto, for the notes of this case). R. H., male, aged 3. Admitted to the Hospital for Sick Children, Toronto, on October 2I, I9I2, with. the complaint of constipation dating from birth. He had showed signs of constipation when three days old, and had had no bowel movements for as long as three weeks at a time, in spite of frequent enemata. The abdomen was very distended. On Nov. 6, I912, Sir Arbuthnot Lane removed the large intestine and anastomosed the ileum to the lower part of the pelvic colon. He made an excellent recovery.

On December 8 it is noted that the remaining part of the pelvic colon had dilated and the abdomen was slightly distended. On January to he was discharged. A note made on May 27, I9I3, says, "Is running around the streets. Has good bowel movements every day. Has a brother two weeks old with the same condition, which started on the second day of life, and is said to be a more severe form of the disease than that from which the patient suffered." I have since heard that this last case died at the age of I $_{5}$ days "from intestinal toxæmia, the result of Hirschsprung's disease." The cases have been reported by Dr. H. T. Machell in the Canadian Journal of Medicine and Surgery, June, I9r3.

Case 5.-J. H., male, aged 9. Admitted to the Hospital for Sick Children, Great Ormond Street, on May 3, I9I3. The abdomen had been distended for four years and the condition was becoming worse. He had suffered from severe attacks of pain and vomiting. He had had no diarrhœa. He suffered from constipation, sometimes having no action of the bowels for ten days. He had some retention of urine. There were five other children in the family, all healthy. The abdomen was distended and peristalsis was visible. The distended large intestine was palpable. On rectal examination, the finger passed into the dilated rectum. The $x$-ray examination showed much stasis and a very dilated sigmoid.

On June 9. Sir Arbuthnot Lane removed the descending and pelvic colon and implanted the cut end of the colon into the side of the rectum. Recovery was satisfactory. On July 28 the boy was much improved in health. The abdomen was flat. He was taking paraffin, and the bowels moved normally each day.

It may be objected that these five cases were of an age suitable for operative measures, and that the means employed could not cope with the condition in infants. Unfortunately, no opportunity has presented itself for employing this method on younger children. The youngest child on whom $I$ have seen ileocolostomy performed was 2 years, and the operation caused no anxiety whatever, the child making a perfect recovery.

The advances recently made in the treatment of congenital pyloric stenosis have shown that gastro-enterostomy can be borne by exceedingly feeble infants. It is reasonable to expect that an ileocolostomy could be performed with even 
POST-MORTEM RECORDS OF 19 CASES OF CONGENITAL ENLARGEMENT

OF THE COLON AND RECTUM AT THE HOSPITAL FOR SICK

CHILDREN, GREAT ORMOND STREET.

\begin{tabular}{|c|c|c|c|c|c|c|c|}
\hline CASE" & Sex & $\begin{array}{c}\text { AGE AT } \\
\text { ONSET } \\
\text { OF } \\
\text { SYM- } \\
\text { PTOAIS }\end{array}$ & $\begin{array}{l}\text { AGK AT } \\
\text { DEATH }\end{array}$ & $\begin{array}{l}\text { TREAT* } \\
\text { NENT }\end{array}$ & $\begin{array}{c}\text { CONDITION OF } \\
\text { COLON }\end{array}$ & $\begin{array}{l}\text { Condirton of } \\
\text { SigMOID }\end{array}$ & $\begin{array}{c}\text { Condition of } \\
\text { RaCTuM }\end{array}$ \\
\hline $\begin{array}{r}\text { I. L. G. } \\
1868\end{array}$ & $\mathbf{M}$ & Birth & $\begin{array}{l}\frac{41}{2} \\
\text { years }\end{array}$ & Medical & "Contracted" & $\begin{array}{l}\text { Dilated and } \\
\text { hypertrophied }\end{array}$ & Not stated \\
\hline 2. H. J. D. & M & Birth & 3 months & Medical & $\begin{array}{l}\text { Hypertrophied } \\
\text { and dilated }\end{array}$ & $\begin{array}{l}\text { Hypertrophied } \\
\text { and dilated, } \\
\text { ulcerated }\end{array}$ & $\begin{array}{l}\text { Thickened and } \\
\text { narrowed } 2^{*} \\
\text { above an us, } \\
\text { circular thick- } \\
\text { ening } 1^{\prime \prime} \delta^{n} \text { in. } \\
\text { extent. }\end{array}$ \\
\hline $\begin{array}{l}\text { 3. F S. } \\
1894\end{array}$ & $\mathbf{M}$ & Birth & 3 years & Medical & Distended & Distended" & $\begin{array}{l}\text { Distended to } \\
3^{\prime \prime} \text { from anus }\end{array}$ \\
\hline 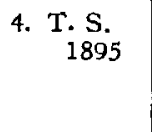 & $\mathbf{M}$ & Birth & 5 months & Medical & $\begin{array}{l}\text { Hypertrophied } \\
\text { and distended }\end{array}$ & $\begin{array}{l}\text { Hypertrophied } \\
\text { and disten- } \\
\text { ded kink at } \\
\text { pelvic brim }\end{array}$ & Normal \\
\hline 5. C. F C. & $\mathbf{F}$ & Birth & 4 months & Medical & $\begin{array}{l}\text { Dilated and } \\
\text { slightly hy- } \\
\text { pertrophied }\end{array}$ & $\begin{array}{l}\text { Elongation of } \\
\text { mesentery }\end{array}$ & Not stated \\
\hline $\begin{array}{c}\text { 6. C. F. G. } \\
1897\end{array}$ & $\mathbf{M}$ & $\begin{array}{c}6 \\
\text { m'ths }\end{array}$ & $\begin{array}{l}3 \text { years } \\
9 \text { months }\end{array}$ & $\begin{array}{c}\text { Medical. } \\
\text { Colos- } \\
\text { tomy }\end{array}$ & $\begin{array}{l}\text { Distended } \\
\text { and slightly } \\
\text { hypertrophied }\end{array}$ & $\begin{array}{l}\text { Distended, } \\
\text { hypertrophied, } \\
\text { ulcerated }\end{array}$ & $\begin{array}{l}\text { Distended and } \\
\text { hypertrophied } \\
\text { to anus }\end{array}$ \\
\hline $\begin{array}{l}\text { 7. H. F. } \\
1899\end{array}$ & $\mathbf{M}$ & Birth & $\begin{array}{c}4 \text { years } \\
9 \text { months }\end{array}$ & Medical & $\begin{array}{l}\text { Dilated and } \\
\text { hypertrophied, } \\
\text { ulcerated }\end{array}$ & Ditto & $\begin{array}{l}\text { Much hyper- } \\
\text { trophied down } \\
\text { to anus }\end{array}$ \\
\hline $\begin{array}{r}\text { 8. S. H. } \\
1899\end{array}$ & $\mathbf{M}$ & Birth & 4 months & Medical & $\begin{array}{l}\text { Dilated and } \\
\text { hypertro- } \\
\text { phied }\end{array}$ & $\begin{array}{l}\text { Dilated and } \\
\text { Thickness it } \\
\text { gressively to }\end{array}$ & $\begin{array}{l}\text { hypertrophied. } \\
\text { acreased pro- } \\
\text { wards rectum }\end{array}$ \\
\hline 9. H, L. & M & Birth & 3 weeks & Medical & $\begin{array}{l}\text { Dilated and } \\
\text { hypertrophied }\end{array}$ & $\begin{array}{l}\text { Dilated and } \\
\text { hypertrophied }\end{array}$ & Not stated \\
\hline $\begin{array}{l}\text { 10. A. R. } \\
1905\end{array}$ & $\mathbf{M}$ & Birth & 10 weeks & Medical & $\begin{array}{l}\text { Slightly dila- } \\
\text { ted }\end{array}$ & $\begin{array}{l}\text { Dilated, thick- } \\
\text { ened, ulcer- } \\
\text { ated }\end{array}$ & $\begin{array}{l}\text { Dilated and } \\
\text { thickened }\end{array}$ \\
\hline
\end{tabular}


ENLARGEMENT OF COLON AND RECTUM 359

POST-MORTEM RECORDS-continued.

\begin{tabular}{|c|c|c|c|c|c|c|c|}
\hline Cast & Sex & $\left|\begin{array}{c}\text { AGE AT } \\
\text { ONSHT: } \\
\text { OF } \\
\text { SVM- } \\
\text { PTOMS }\end{array}\right|$ & $\begin{array}{l}\text { AGR AT } \\
\text { DEATH }\end{array}$ & $\begin{array}{c}\text { TREAT- } \\
\text { MENT }\end{array}$ & $\begin{array}{l}\text { Condition of } \\
\text { Colon }\end{array}$ & $\begin{array}{l}\text { CondITION oF } \\
\text { SIGMOID }\end{array}$ & $\begin{array}{c}\text { Condotion of } \\
\text { KeCTUM }\end{array}$ \\
\hline $\begin{array}{l}\text { 11. C. B. } \\
1905\end{array}$ & $\mathbf{M}$ & $\begin{array}{c}\text { Not } \\
\text { known }\end{array} \mid$ & $\begin{array}{c}10 \\
\text { months }\end{array}$ & $\begin{array}{c}\text { Died on } \\
\text { admission }\end{array}$ & Dilated & Dilated & "Ballooned" \\
\hline $\begin{array}{l}\text { 12. A. S. } \\
1905\end{array}$ & F & Birth & $\begin{array}{c}\text { I year } \\
3 \text { months }\end{array}$ & $\begin{array}{c}\text { Ileum } \\
\text { anasto- } \\
\text { mosed to } \\
\text { rectum }\end{array}$ & Hypertrophied & Hypertrophied & $\begin{array}{l}2^{n} \text { from anus } \\
\text { circular band } \\
\frac{1}{4} \text { in. thick }\end{array}$ \\
\hline 13. J. S. & $\mathbf{M}$ & Birth & 2 months & Medical & Hypertrophied & Hypertrophied & $\begin{array}{l}\text { Last part of } \\
\text { rectum quite } \\
\text { thickened }\end{array}$ \\
\hline $\begin{array}{l}\text { 14. V. R. } \\
1908\end{array}$ & $\mathrm{~F}$ & $\begin{array}{c}\text { Aged 2 } \\
\mathrm{m}^{\prime} \text { ths }\end{array}$ & 4 months & $\mid \begin{array}{c}\text { Died on } \\
\text { admission }\end{array}$ & Enlarged & Much enlärged & $\begin{array}{l}\text { Hard and } \\
\text { thickened in } \\
\text { lower part. } \\
\text { Hypertrophy } \\
\text { of circular coat }\end{array}$ \\
\hline $\begin{array}{r}\text { 15. F. C. } \\
1908\end{array}$ & $\mathbf{M}$ & Birth & 11 months & $\begin{array}{c}\text { Colosto- } \\
\text { my, Ileo- } \\
\text { sigmond- } \\
\text { ostomy }\end{array}$ & $\begin{array}{l}\text { Dilated and } \\
\text { thickened }\end{array}$ & $\begin{array}{l}\text { Dilated and } \\
\text { thickened }\end{array}$ & $\begin{array}{l}\text { Dilated and } \\
\text { thickened to } \\
4 \text { in. from } \\
\text { anus. }\end{array}$ \\
\hline 16 I. R. & $\mathbf{M}$ & Birth & $\begin{array}{c}2 \text { years } \\
7 \text { months }\end{array}$ & $\begin{array}{l}\text { Resection } \\
\text { of } 1 \mathrm{ft} \text { of } \\
\text { sigmoid }\end{array}$ & $\begin{array}{l}\text { Distended, } \\
\text { thickened }\end{array}$ & No & note \\
\hline $\begin{array}{l}\text { 17. D.S. } \\
1910\end{array}$ & $\mathbf{M}$ & Birth & $\begin{array}{c}3 \text { years } \\
8 \text { months }\end{array}$ & $\begin{array}{l}\text { Appendi- } \\
\text { costomy }\end{array}$ & \multicolumn{2}{|c|}{ Dilated and hypertrophied } & Normal \\
\hline $\begin{array}{r}\text { 18. E. H. } \\
1911\end{array}$ & $\mathbf{M}$ & $\begin{array}{c}3 \frac{1}{2} \\
\text { years }\end{array}$ & 4 years & Medical & Distended & $\begin{array}{l}\text { Greatly disten- } \\
\text { ded and some } \\
\text { hypertrophy }\end{array}$ & $\begin{array}{c}\text { Greatly } \\
\text { hypertrophied }\end{array}$ \\
\hline $\begin{array}{l}\text { 19. R. L. } \\
1912\end{array}$ & $\mathbf{M}$ & Birth & 12 years & $\begin{array}{c}\text { Resection } \\
\text { of colon }\end{array}$ & \multicolumn{2}{|c|}{ Dilated and hypertrophied } & $\begin{array}{l}\text { Very dilated } \\
\text { and hyper- } \\
\text { trophied to } \\
\text { anus. }\end{array}$ \\
\hline
\end{tabular}


greater safety, as patients with congenital colon disease do not as a rule present serious symptoms until rather later in life, and they are never so feeble as the infant with pyloric stenosis, provided that medical treatment has not been persisted in too long. I believe that an ileocolostomy would give temporary relief and tide the patient over for one or two years until the radical operation could be performed.

The table on pp. $35^{8}, 359$, shows the chief findings at the post-mortem examination of nineteen cases, and a short account of the cases treated by Sir Arbuthnot Lane by anastomosis and resection.

I am much indebted to the Medical Committee of the Hospital for Sick Children, Great Ormond Street, London, for permission to publish these cases.

\section{REFERENCES.}

Hirschsprung, Jahrb. f. Kinderheilk. 1888.

JAYLe, Presse Med., Paris, I90, xvii, 813.

FINNEY, Surg. Gyn. Obstet. r908, vi. 6.

TREVES, Lancet, I $898, \mathrm{i}, 276$.

Wilkie, Edin. Med. Jour., I909, ï, and Oct., Igro.

Fenwick, Brit. Med. Jour., 1900, ii, 564.

Bart,ING, Lancet, I9I3, i, 231.

Duval, Rev. de Chir.s Paris, Igog, xl, 506.

Lowensteln, Centralb. f. Allg. Path., I907, xviii, 929.

Terry, Jour. Amer. Med. Assoc., Chicago, I9I r, Ivii, 73 I.

Cheadle, Lancet, $1898, \mathrm{i}, 399$.

Fletcher ANd Robinson, Brit. Med. Jour., I907, i, $37^{\circ}$ 